\title{
SIMULATION TESTING OF THE E-KANBAN TO INCREASE THE EFFICIENCY OF LOGISTICS PROCESSES
}

\author{
Pekarcikova, M.; Trebuna, P.; Kliment, M.; Mizerak, M. \& Kral, S. \\ Technical University in Kosice, Faculty of Mechanical Engineering, Institute of Management, \\ Industrial and Digital Engineering, Nemcovej 32, 04200 Kosice, Slovakia \\ E-Mail: miriam.pekarcikova@tuke.sk, peter.trebuna@tuke.sk, marek.kliment@tuke.sk, \\ marek.mizerak@tuke.sk,kral@slm.sk
}

\begin{abstract}
Combining lean techniques with software and digital tools currently creates a high potential to be more efficient, faster, and better. The reason is that the Lean tools are more standardized, more transparent than others and are limited to the necessary work. The case study aimed to create a model of the current state, testing the productivity and efficiency of production and logistics flows and then design optimization options using software support. The analysis resulted in the design and testing of e-Kanban in terms of business practice to increase the efficiency of logistics processes using selected elements of modeling and simulation. The design consisted in the implementation of a selected Lean tool e-Kanban, its testing and optimal setup using the simulation software Tecnomatix Plant Simulation. The created simulation model can be used in connection with the solution of process digitization in the researched company.

(Received in November 2020, accepted in February 2021. This paper was with the authors 1 week for 1 revision.)
\end{abstract}

Key Words: Logistics, Lean Tools, Simulation, E-Kanban

\section{INTRODUCTION}

\subsection{Intensification of Industry 4.0 technology}

Intensification of Industry 4.0 technology within the digitization of the Supply chain means increasing agility and acquiring intelligent capabilities of the system as a whole. The greatest importance is the introduction of the so-called cognitive technologies (machine learning, speech recognition, spatial orientation, etc.) thanks to which systems change their agility into intelligence, the so-called collective intelligence, i.e. systems not only move in space on their own, but also communicate with each other, learn and try to go through the transformation process as efficiently as possible [1-4]. In the context of the Supply chain, there are obvious benefits in combining the latest technologies with specific techniques of industrial practice such as Just in Time, resp. Just in Case and Kanban. A platform is being created to interconnect the individual subsystems of the company, which would work with information in real time. Quality communication in production and logistics processes enables the production of highquality products in shorter production cycles and responds to customer demand in terms of diversity and individuality of products, as well as minimizing losses during operations [5-9].

Information and communication technologies increase the potential associated with the collection and processing the big data from the production and logistics processes in real-time. This opens up opportunities for all participants in the value chain to communicate with each other, thus creating a network of entities that can communicate effectively, operatively and in real-time and respond to various situations. The interaction of sensors, data and analytical data is the catalyst for this e-revolution. This creates space for the customer, who will be able to personalize their order [10-13].

The integrated Supply chain included [13-15]:

- integration the process of planning, optimization, visualization and management to ensure optimal balance of the whole value chain, respectively net; 
- calculation of relevant logistics costs which are suitable for different variants of the supply process;

- standardization the planning process - focus on optimization of the value chain, respectively value net in the way of very inteactive communication of each other.

The integrated supply chain aims to provide system support for logistics processes using the principles of Lean Manufacturing, i.e. electronic records of movements of individual items in the warehouse, material flow management upon receipt, quality control, warehousing, expenditure from the warehouse to production and preparation for dispatch in real-time. Equipping the warehouse workers with mobile terminals that monitor their performance and enable it to be measured and evaluated is important for improving and increasing the efficiency of warehouse processes. The 25 most effective lean production strategies are elaborated in Fig. $1[1,2,11]$.

\begin{tabular}{|c|c|c|c|c|}
\hline $5 \mathrm{~S}$ & Heijunka & Kanban & Poka-Yoke & $\begin{array}{c}\text { Standardized } \\
\text { Work }\end{array}$ \\
\hline Andon & Hoshin Kanri & KPIs & $\begin{array}{l}\text { Root cause } \\
\text { analysis }\end{array}$ & Takt Time \\
\hline $\begin{array}{c}\text { Bottleneck } \\
\text { analysis }\end{array}$ & Jidoka & Muda & SMED & TPM \\
\hline $\begin{array}{l}\text { Continuous } \\
\text { flow }\end{array}$ & Just in Time & OEE & Six Big Losses & $\begin{array}{l}\text { Value Stream } \\
\text { Mapping }\end{array}$ \\
\hline Gemba & Kaizen & PDCA & SMART Goals & Visual Factory \\
\hline
\end{tabular}

Figure 1: The 25 most effective lean production strategies.

Among others, it is a great benefit to reduce bureaucracy about paper records and document completion and to reduce errors. Already when receiving the material into the warehouse, it is advisable to have developed a warehousing strategy, which creates a precondition for the correct location of entrances. In the process of removal from storage, it is also the application of information and communication technologies as very effective. Pick to Light technology (using light signalling defines the position with the required component, one of the techniques of the Poka-Yoke methodology - elimination of unintentional error rate) [13-15].

\subsection{The Kanban tool in Tecnomatix Plant Simulation}

The Kanban concept is a logistics concept focused on supplying production lines, accepted and used primarily in the automotive industry. Kanban is based on self-regulatory circuits that are regulated on demand. The principle of Kanban can be explained, for example, as the functioning of a supermarket. Since the consumer can buy what he needs in the supermarket, he empties certain goods from the shelves. If there is a high demand for any goods, the shelf will be emptied and supermarket employees will replenish it from the warehouse, resp. intermediate from the storage as required. The author Bangsow states in his publication [16] that the functioning of a supermarket is implemented into a production process. In Kanban's control, this principle is transferred to the production process, for example:

- assembly sub processes take pieces from the warehouse/shelf according to their own needs,

- upstream departments or suppliers fill the warehouse/shelf themselves.

Used software Tecnomatix Plant Simulation has the possibility of using lean tools in simulations such as Kanban, Value stream mapping, Flow control, etc.

Kanban tools are part of the main toolbar of TX Plant Simulation 15.2. It is a traction system that periodically tests the assumptions for the relocation of processes and releases them only when all conditions are met. The TX Plant Simulation software offers four Kanban tools to 
choose from KanbanSource, KanbanSingleProc, KanbanBuffer and KanbanChart (see Fig. 2) $[6,16]$.

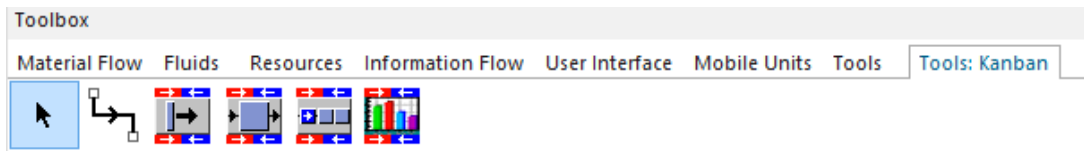

Figure 2: Kanban tools in TX Plant Simulation 15.2.

\section{CASE STUDY}

\subsection{Problem definition}

The case study below was prepared as the request of the company to increase the efficiency of logistics processes in the production in question. This is a complex logistical problem due to the nature of the products that are manufactured in the company. It was necessary to process the analysis of the material flow and at the expense of the outputs from the analysis to process the optimization proposal in conjunction with the fulfillment of the goal. Lean tools (Gemba, Value stream mapping, see Fig. 3, 3Mu, Bottleneck analysis, Continuous flow, Kanban) were used in the process of analysis and subsequent design in combination with TX Plant Simulation software support. This combination made it possible to create a dynamic simulation model that can be tested at different inputs, respectively tracking enterprise-defined goals and is a step towards creating a Visual Factory and Digital Factory.

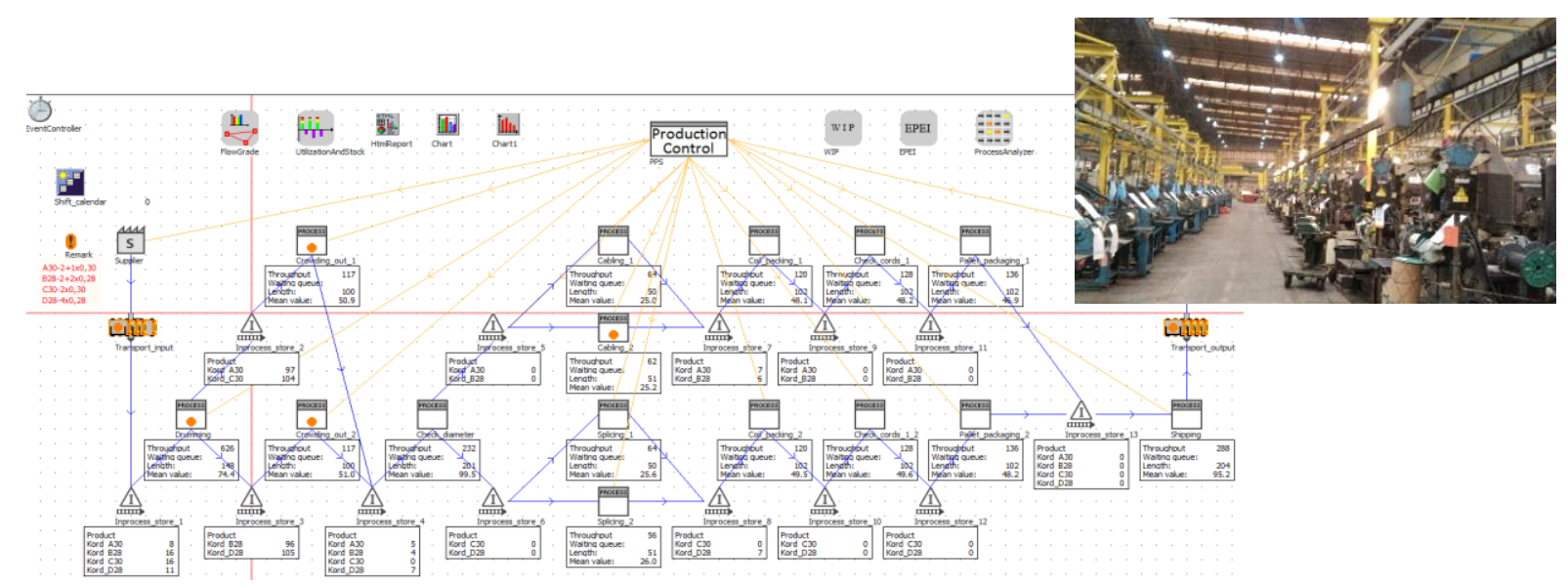

Figure 3: VSM model in TX Plant Simulation in the researched company.

\subsection{Creation and testing e-Kanban simulation model using TX Plant Simulation}

The production process processed in a case study, elaborated in the case study deals with the processing of steel wires and cables pass. The process model of the current state was processed based on a detailed analysis in the surveyed company, using the Value stream mapping method, however, it was not the aim of this study. The current state is modelled and testing through TX Plant Simulation software, simulation time is set to 12 hours, i.e. for one work shift. It is a production line where raw steel wire enters the production process as a semi-finished product. The first operation is drumming, whereby the input semi-finished product is unwound and then wound on drums that are suitable on the given line. After this operation, the already rewound wire is waiting for the next operation, which is drawing. However, it is divided into four workplaces depending on the length of the wire to be drawn at each workplace. Since each length has its specifics, the longer the steel wire is drawn to a thinner diameter, the longer it takes to stand. The length of the cables to be pulled out depends on the customer's specific 
order. Subsequently, we continue the inspection of drawn cables, which is based on a laser, as it is specific and can measure the quality of the entire wire fibre along its entire length. The wire pulled out to the cabling workplace or the braiding workplace.

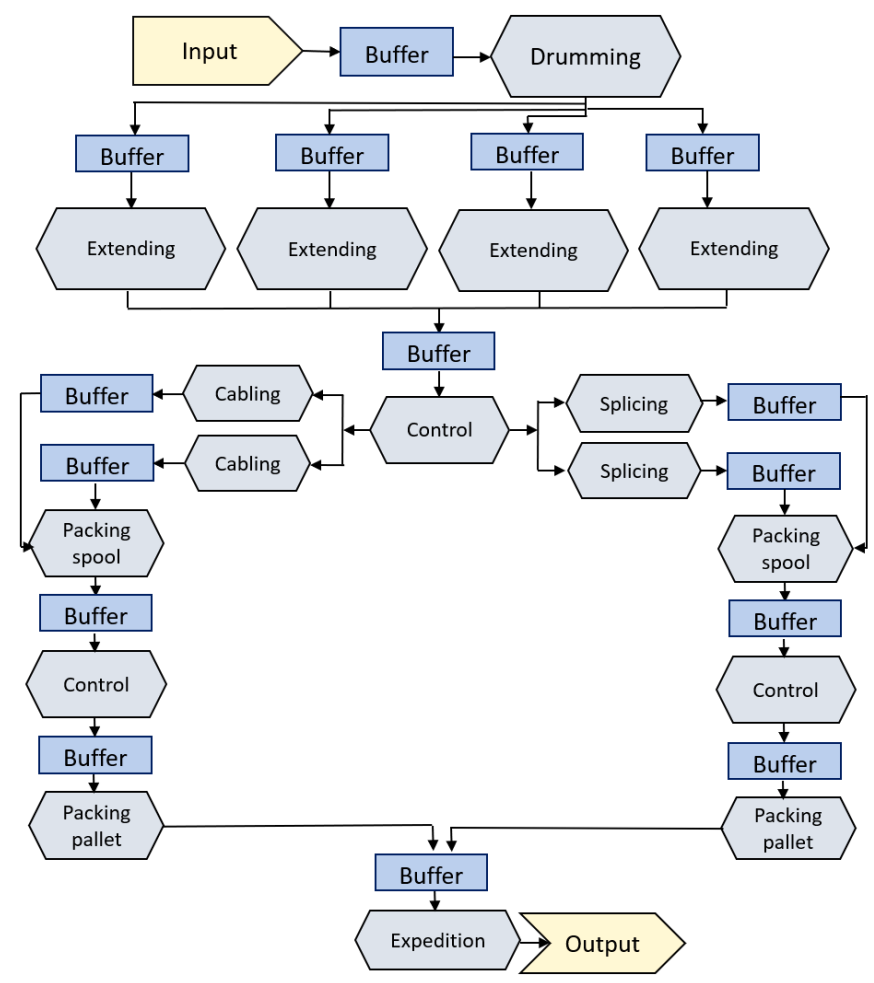

Figure 4: Scheme of the current state.

Table I: Input data for current state model creation.

\begin{tabular}{|c|c|c|c|c|l|}
\hline Process & $\begin{array}{c}\text { Cycle time } \\
\text { (DDD:HH:MM:SS.XXX) }\end{array}$ & $\begin{array}{c}\text { Availab. } \\
(\%)\end{array}$ & $\begin{array}{l}\text { Set-up time } \\
\text { (MM:SS.XXX) }\end{array}$ & $\begin{array}{c}\text { MTTR } \\
\text { (MM:SS.XXX) }\end{array}$ & \multicolumn{1}{|c|}{ Process description } \\
\hline Drumming & $1: 15: 00$ & 100 & $0: 00.0000$ & 0.0000 & $\begin{array}{l}\text { Input wire/semi-finished product is rewound on } \\
\text { drums suitable for machines used in the } \\
\text { production process. }\end{array}$ \\
\hline Extending & $4: 40: 00-4: 55: 00$ & 95 & $10: 00.0000$ & $5: 00.0000$ & $\begin{array}{l}\text { The wire blank is extending to the desired } \\
\text { fibres diameter and wound on a spool for } \\
\text { transport to the next process. Different } \\
\text { diameters have different processing times, the } \\
\text { thinner the fibres the longer the processing } \\
\text { time. }\end{array}$ \\
\hline $\begin{array}{c}\text { Control } \\
\text { the } \\
\text { diameter }\end{array}$ & $2: 00$ & 100 & $0: 00.0000$ & 0.0000 & $\begin{array}{l}\text { Diameter control using a high-precision laser } \\
\text { station. This inspection ensures the required } \\
\text { quality of the entire length of the fibres. }\end{array}$ \\
\hline $\begin{array}{c}\text { Cabling } \\
\text { (Mpribres }\end{array}$ & $3: 10: 00-3: 20: 00$ & 95 & $10: 00.0000$ & $5: 00.0000$ & $\begin{array}{l}\text { By the production of cordless cords, the fibres } \\
\text { are trated by entanglement on a machine and } \\
\text { thus the desired product is obtained. }\end{array}$ \\
\hline $\begin{array}{c}\text { Splicing } \\
\text { Packing } \\
\text { spool }\end{array}$ & $2: 15: 00-2: 25: 00$ & 95 & $10: 00.0000$ & $5: 00.0000$ & $\begin{array}{l}\text { By the production of core cords, the fibres are } \\
\text { treated by cabling and the process consists in } \\
\text { braiding the central core with fibres. }\end{array}$ \\
\hline $\begin{array}{c}\text { Control } \\
\text { the spool }\end{array}$ & $6: 00$ & 100 & $0: 00.0000$ & 0.0000 & $\begin{array}{l}\text { The spools must be tightly wrapped with plastic } \\
\text { film to secure the cord against unintentional } \\
\text { unwinding during transport. }\end{array}$ \\
\hline $\begin{array}{c}\text { Packing } \\
\text { pallet }\end{array}$ & $11: 00$ & 100 & $0: 00.0000$ & 0.0000 & $\begin{array}{l}\text { Each spool comes for a final inspection where } \\
\text { the specified length is cut, and its parameters } \\
\text { are tested. }\end{array}$ \\
\hline Expedition & $15: 00$ & 100 & $0: 00.0000$ & 0.0000 & $\begin{array}{l}\text { Pallets are shipped to the customer according to } \\
\text { the current order. }\end{array}$ \\
\hline
\end{tabular}


The division of the wires into individual workplaces depends on whether the wires will have a core, then they will enter the cabling process, creating a cord without a core, and if it does not have a core, the wire will enter the entanglement process to form a cord with the core. After wiring or braiding, the already finished cords proceed for inspection and final packaging. The scheme of the current state clearly and unambiguously describes the whole process of material flows with the emphasis on work-in-progress during the value chain. (see Fig. 4, Table I).

Based on the diagram in Fig. 3 and Table I a simulation model of the production process was created in the environment of the simulation program TX Plant Simulation ver.15.2. The 3D model is in Fig. 5 and the 2D model with the illustration of the Sankey diagram in Fig. 6.

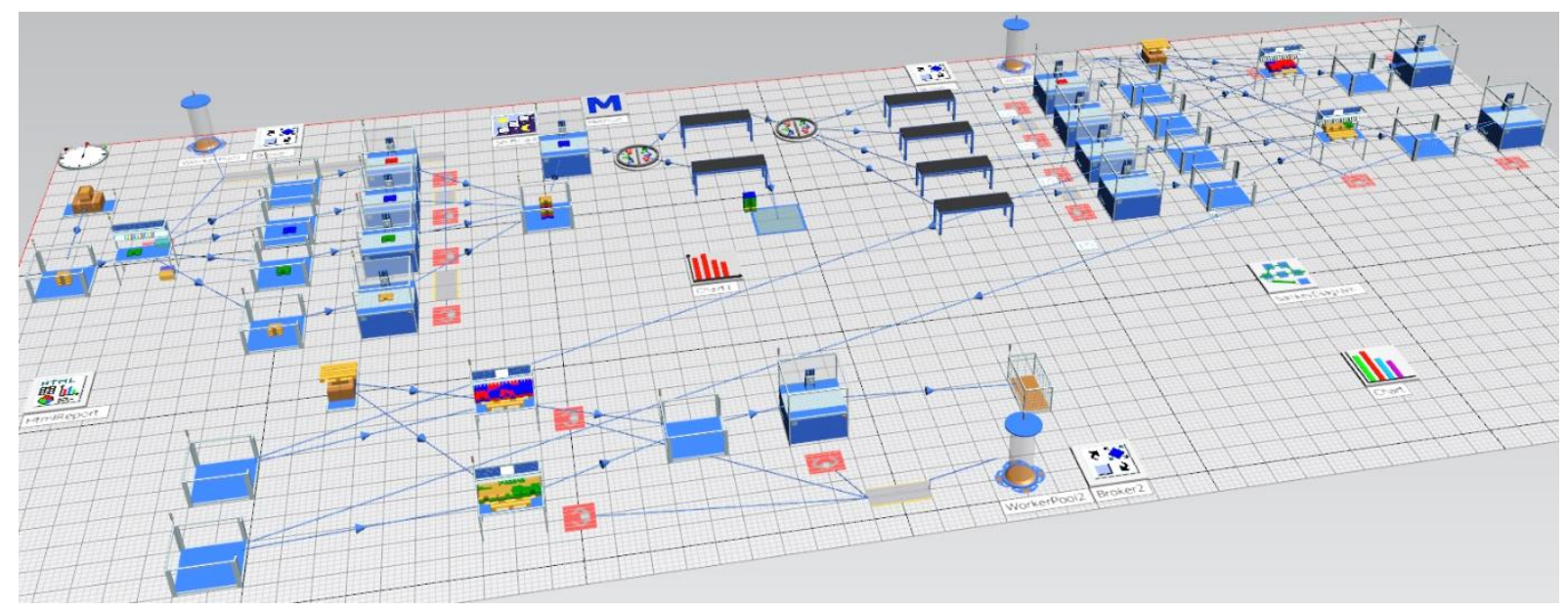

Figure 5: Production and logistics flow - current state simulation 3D model.

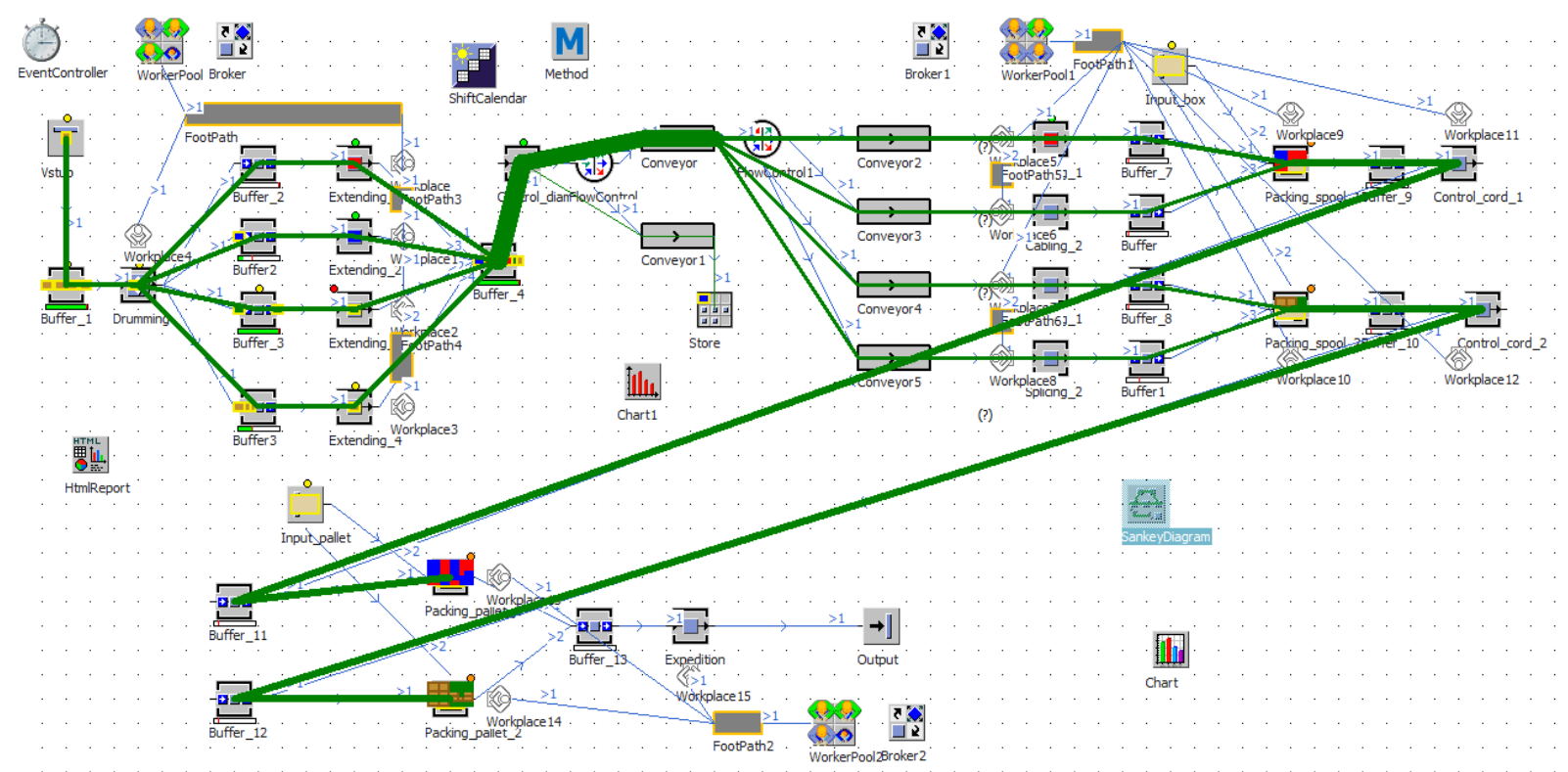

Figure 6: Production and logistics flow - current state simulation 2D model.

\subsection{Statistical outputs of selected attributes in the current simulation model}

The statistical overview of individual operations in the current simulation model shows the performance of individual operations in a graphical display. The most extracted operation was to control the diameter of the wires after the extending process, which took almost $65 \%$ of the time (see Fig. 7 a). There was only one blocked operation in the graphics report, and that was drumming, which accounted for almost $55 \%$ of the time. Up to $3 \%$ of machine setting operations were necessary, as during extending, splicing, and cabling the individual machines 
must be adjusted according to the customer's order. Among the most awaiting operations representing $100 \%$ were the packaging of spools and the packaging of pallets. Suspended and unsuccessful operations, which could have arisen due to incorrect settings, poor material quality, etc., are found in addition to the packaging of spools in each operation. Occupancy of the individual buffer in the whole logistics flow is in Fig. 7 b.
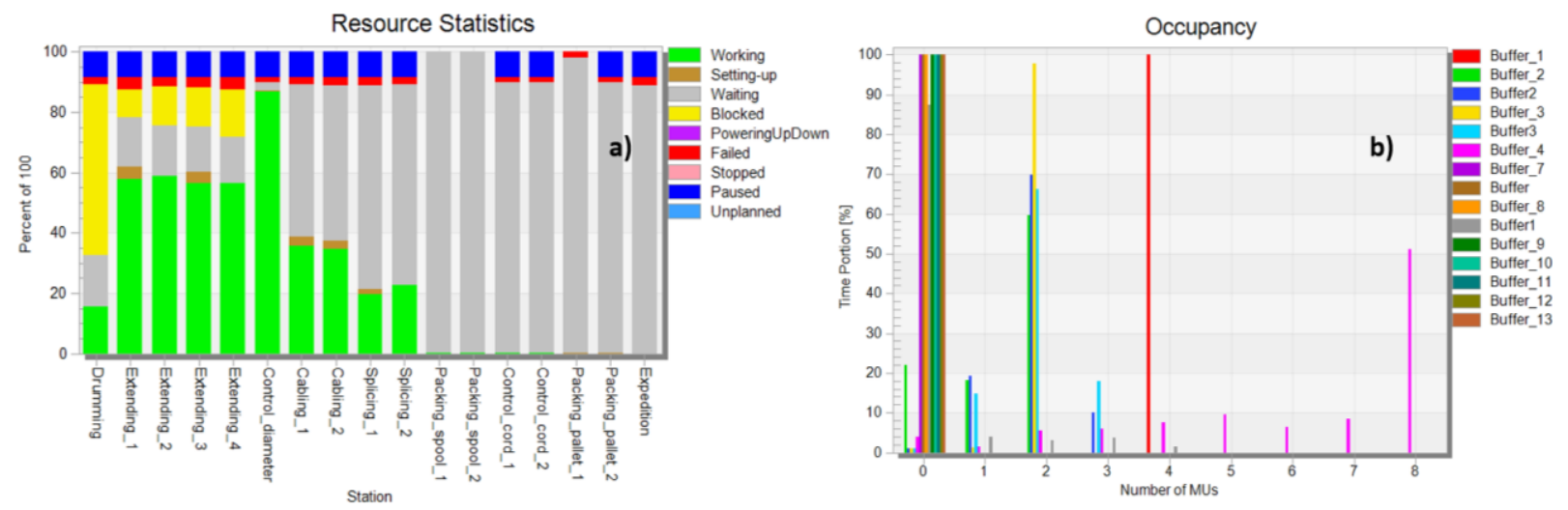

Figure 7: Statistical overview of the performance of individual operations - current state.

\section{RESULTS AND DISCUSSION}

The proposed simulation model aims to improve and streamline the production and logistics process, which is to facilitate the work and thus simplify the movement of material, of course, to set aside excess downtime, which does not add any added value to the product. The main indicators for monitoring efficiency are material flow and performance of operations. To make it more efficient, the Kanban system is used as a tool for lean production. Based on the outputs from the simulation of the current state model, it was found that there are places in the production process that are a problem, they can be considered as bottlenecks. The basic parameters from the current state are unchanged, i.e. the simulation time remains set at 12 hours, i.e. for one working change. In the beginning, as in the current state, steel wire enters the production process. As this is a newly proposed state of the simulation, its essence is to simplify and clarify the production process using a lean manufacturing tool, specifically the Kanban system. The 2D model of the proposed simulation is in Fig. 8 and the 3D model is processed in Fig. 9.

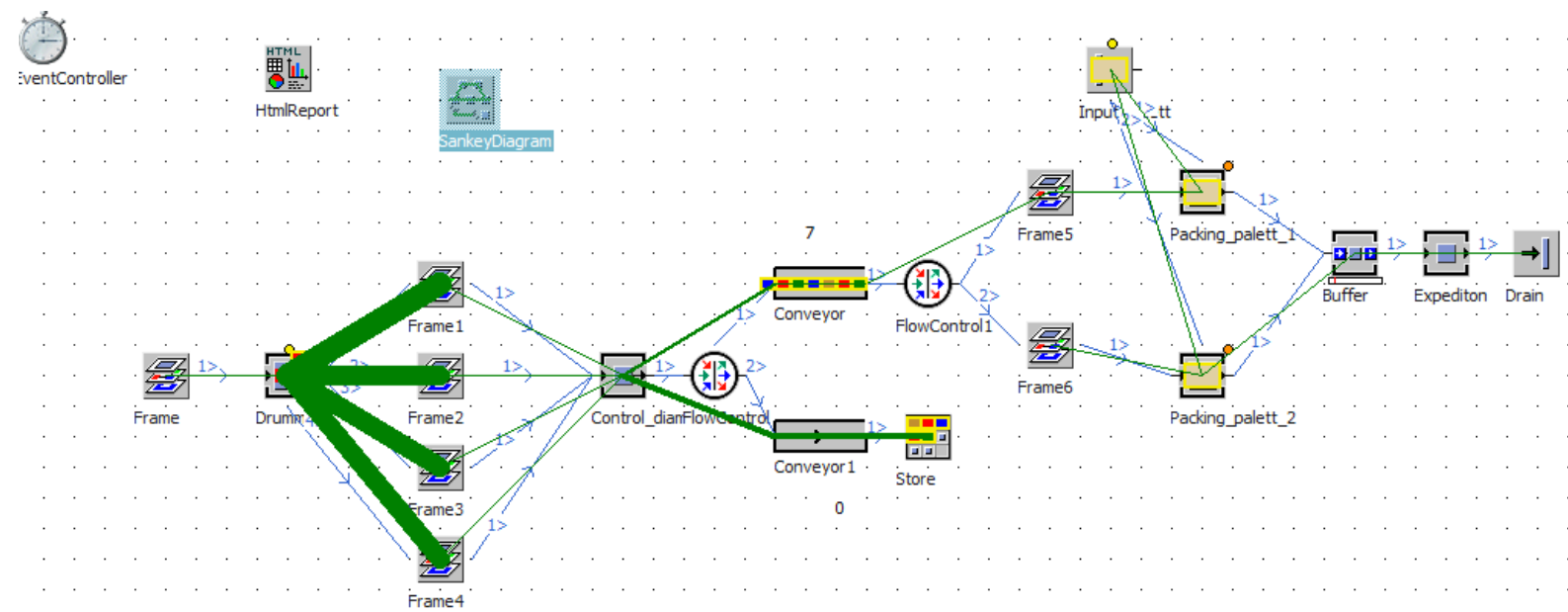

Figure 8: Production and logistics flow - proposed simulation 2D model. 


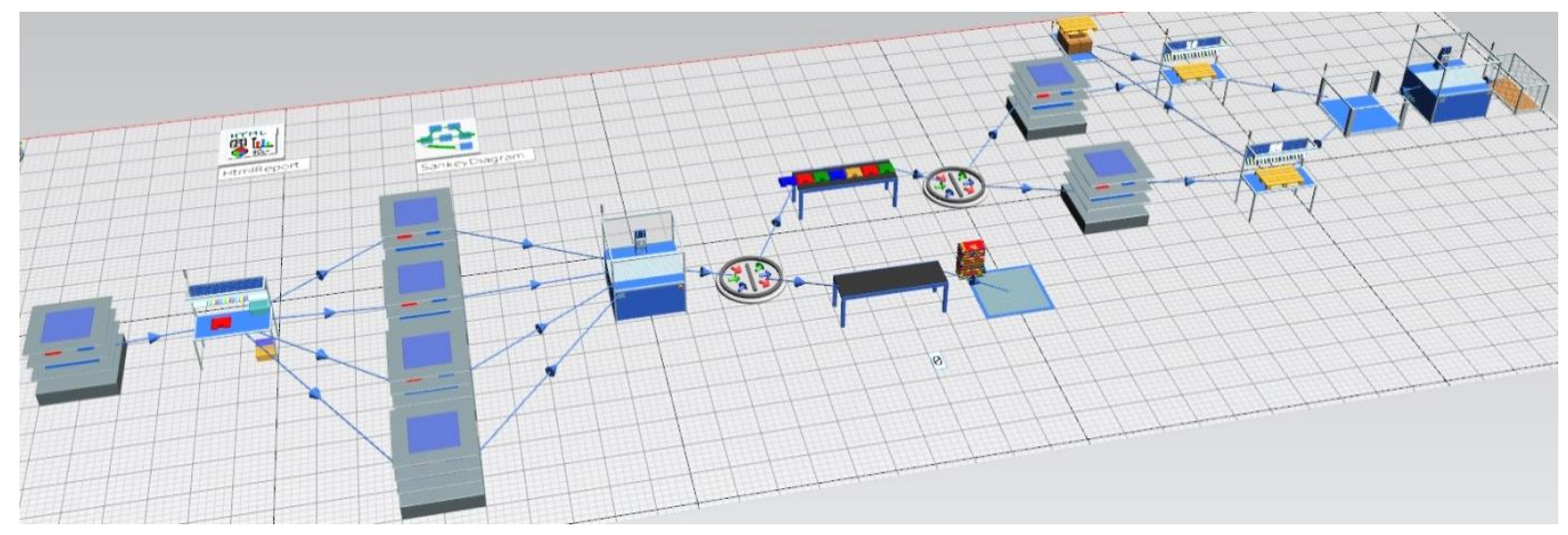

Figure 9: Production and logistics flow - proposed simulation 3D model.

After the steel wire enters the production process, it travels directly to the drumming process, and then the wires are divided into individual frames, each with its system, in which a Kanban system is used, and instead of standing in the intermediate warehouse, the wires are directly drawn to the required length. After the pulling process, the wires travel for control, which is unavoidable. Defective pieces are forwarded to the warehouse using a conveyor, suitable and satisfactory pieces are forwarded by another conveyor to the process of entanglement and cabling, which depends on the customer's order. This is where the biggest change takes place, as it is not necessary to divide the entanglement workplace into two workplaces, and the same has happened with cabling. The next step in the production process is the entry of the pallet, which is necessary in the process of packaging the pallets, which occurs after cabling and entanglement. Already packaged coils travel to the intermediate warehouse and then for shipment to the customer. The frame element in the proposed state is a group of several operations, while after a detailed analysis it is possible to see what is hidden under the item. It is a lean manufacturing tool, the Kanban system, which aims to simplify and streamline the entire production process. Fig. 10 describes the first site, resp. Frame_1, which focuses on the extraction process. Steel wire enters the process via KanbanSource, in this case, type A_30, proceeds to KanbanBuffer, i.e. intermediate storage, where the minimum capacity is 10 and maximum 50, but if it reaches the intermediate storage 15 pieces, then Station pulls these semi-finished products for the process hauling. The processing time of this station is 4 hours and 40 minutes and the setting time is 20 minutes. Subsequently, the wires travel to KanbanSingleProc, where the capacity is 100 pcs (see Fig. 11).

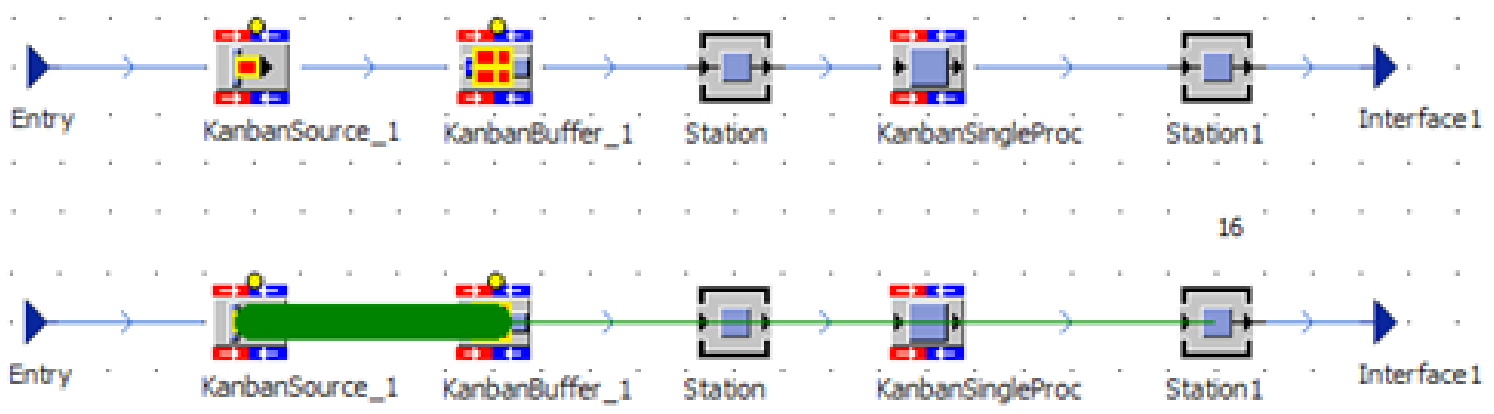

Figure 10: Kanban system - Frame_1 for product A_30. 


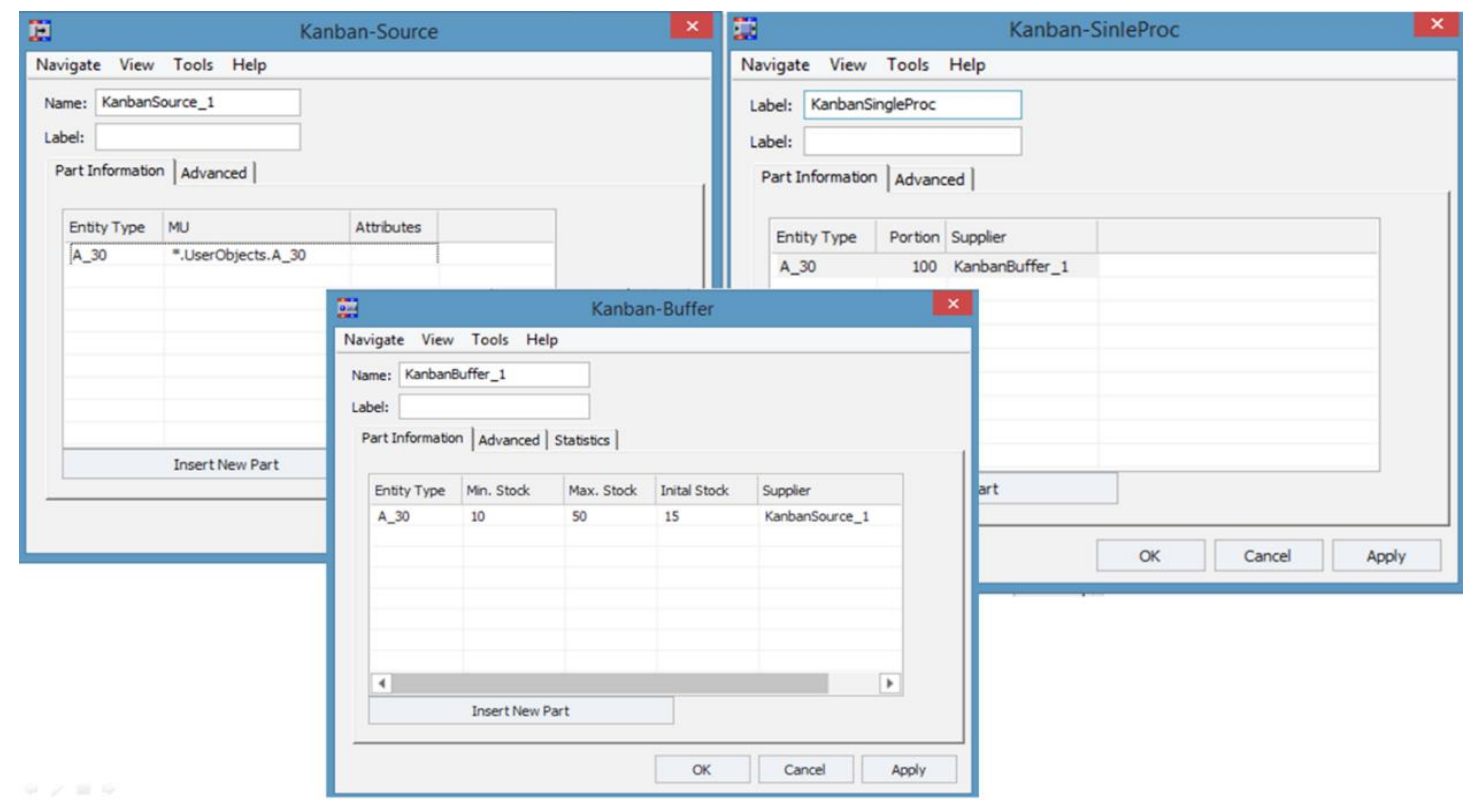

Figure 11: Settings: KanbanSource, KanbanBuffer, Kanban-SingleProc for product A_30.

Fig. 12 shows frame_6 in the 2D model and Fig. 13 in the 3D model. Through implemented Kanban system, work-in-progress, downtimes were reduced and time, but also material flow became more efficient. While in the current state there were two processes of splicing and two cablings in the model, in the proposed state the two processes were merged into frames, which simplified the whole process. Buffer for work-in-progress is not filled, waiting times for individual processes have been reduced and material flow is thus smoother.

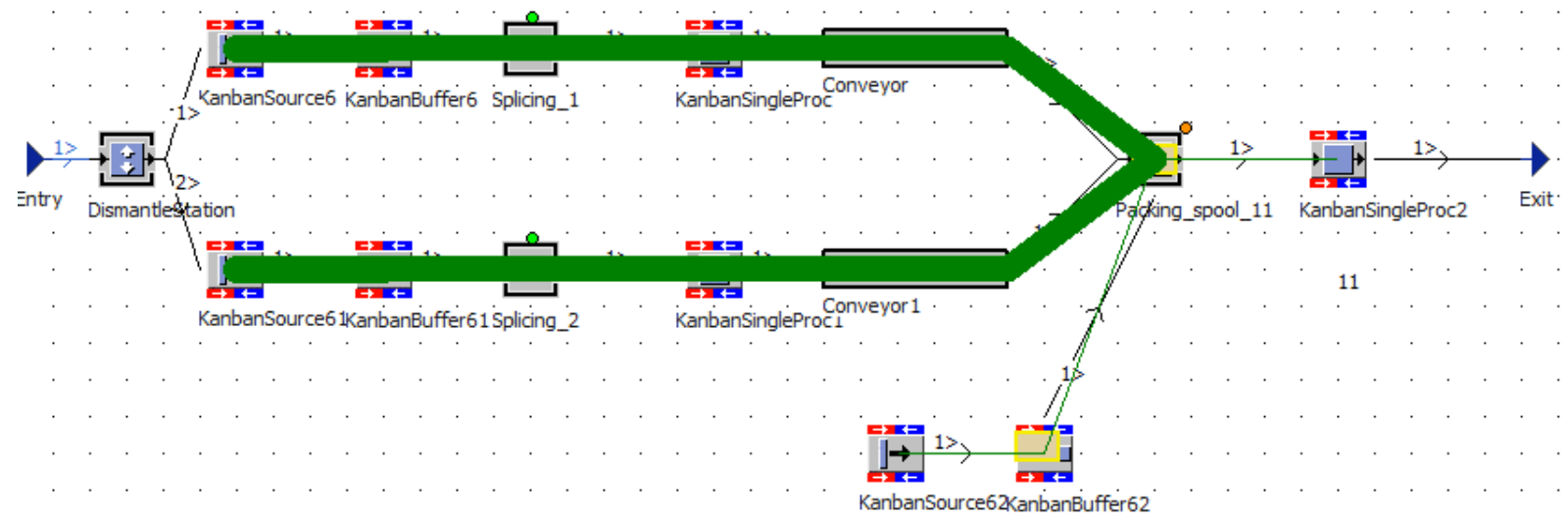

Figure 12: Kanban in the proposed 2D simulation model.

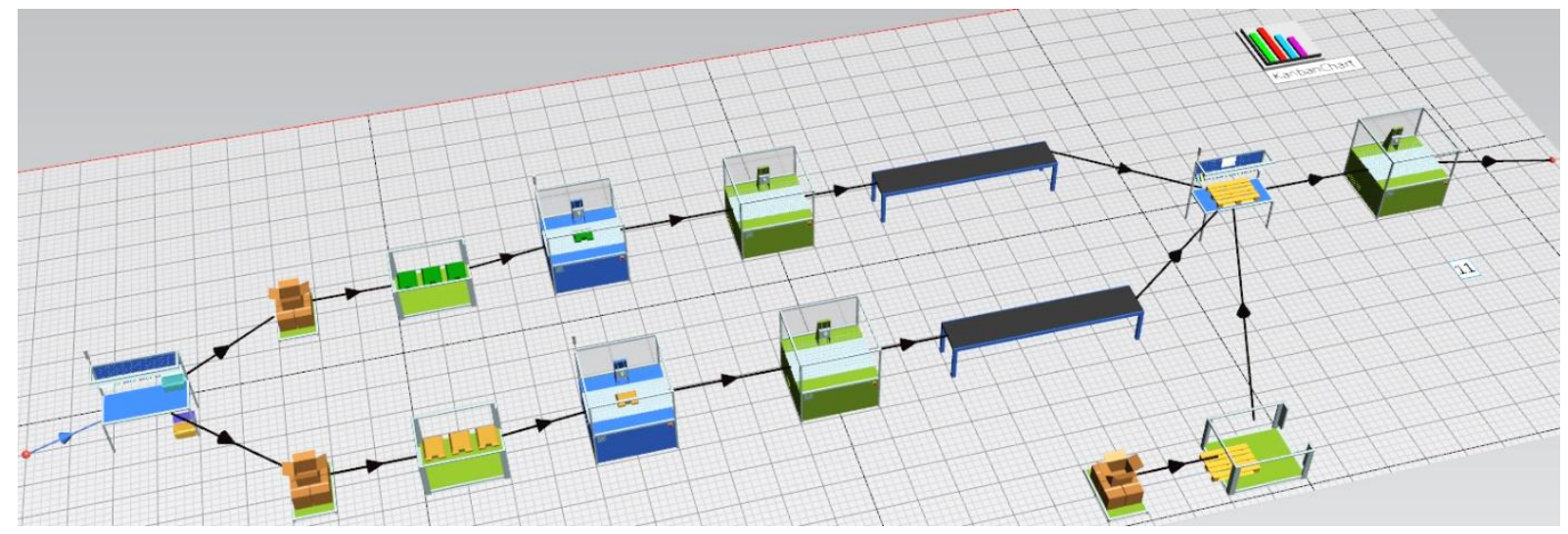

Figure 13: Kanban in the proposed 3D simulation model. 
The main difference between the current and the proposed simulation model shown in the graphical representation in the diagram (see Fig. 14). At first glance, the reduction of buffers with work-in-progress, non-branching of splicing and cabling operations, and thus the scheme is clearer and more readable. The reduction is caused precisely thanks to the lean manufacturing tool - Kanban system. Since in the current state the buffers with work-in-progress were flooded and waiting for individual operations, the proposed model using Frames elements, which operate based on the Kanban system. These are the processes of extending, splicing and cabling. This has made production more efficient and produces more.

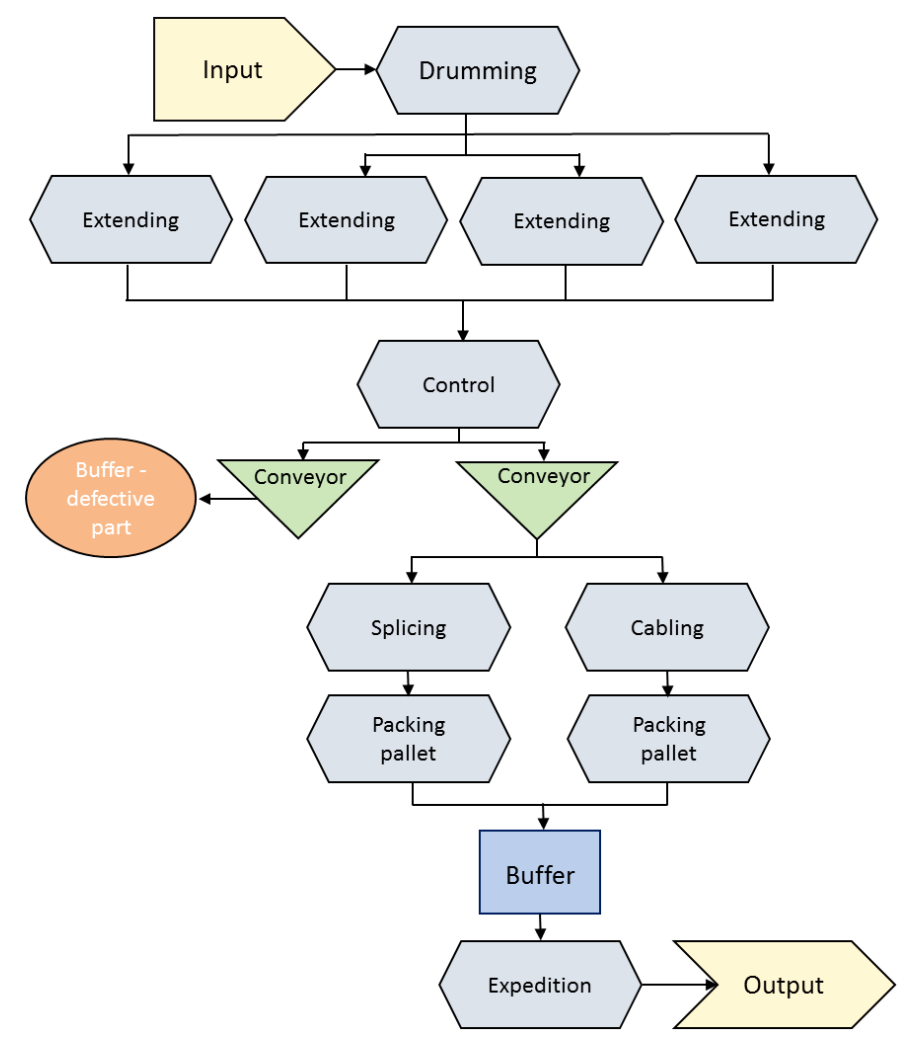

Figure 14: Diagram of the proposed simulation model.

From the current state simulation of the steel cord production were several types of waste identified. Buffers were flooded, operations were many times cancelled or suspended and there was an inefficient flow of material. The production line was not efficiently balanced. For the analysis of the current state, the proposal was made to streamline logistics flows through the lean production tool Kanban because is based on accurate deliveries in time and quantity. The control of concrete tasks through regulated consumption has replaced the non-functional scheduling of tasks used in the company. The interconnection between individual operations thus streamlined the smooth material flow and increased the productivity of individual activities. The opaque, inefficient and congested current simulation model has been replaced by the e-Kanban simulation model.

The main goal was to map the material flow and efficiency of operations and to design a model for streamlining logistics flows in the production process. From the comparison of the current and the proposed model, it can be stated, that while the number of inputs in the current state ranges from 0 to 94 in a 12-hour simulation run, in the proposed state in 12 hours the material flow ranged from 1 to 64 . However, despite the lower number of inputs, the outputs were several times higher. In the current state, the number of outputs was from 0 to 108, the proposed model produced from 0 to 572 outputs. While in the drumming process - current state the number of inputs was 36 and the number of outputs increased cca fourfold, in the drumming 
process - a proposal the number of inputs was 14 and the number of outputs increased more than forty times, see in Table II and Table III. In addition to increasing material flow efficiency, the Kanban system simplified the operation of production processes, buffers were not overfilled and work-in-progress was reduced.

Table II: Material flow properties after current state simulation.

\begin{tabular}{|l|c|c|c|c|c|c|c|c|}
\hline Object & $\begin{array}{c}\text { Number } \\
\text { of } \\
\text { entries }\end{array}$ & $\begin{array}{c}\text { Number } \\
\text { of exits }\end{array}$ & $\begin{array}{c}\text { Minimum } \\
\text { contents }\end{array}$ & $\begin{array}{c}\text { Maximum } \\
\text { contents }\end{array}$ & $\begin{array}{c}\text { Relative } \\
\text { empty }\end{array}$ & $\begin{array}{c}\text { Relative } \\
\text { full }\end{array}$ & $\begin{array}{c}\text { Relative } \\
\text { occupation } \\
\text { without } \\
\text { interruptions }\end{array}$ & $\begin{array}{c}\text { Relative } \\
\text { occupation } \\
\text { with } \\
\text { interruptions }\end{array}$ \\
\hline Input & 41 & 40 & 0 & 1 & $0.00 \%$ & - & $100.00 \%$ & $100.00 \%$ \\
\hline Extending_1 & 36 & 35 & 0 & 1 & $1.03 \%$ & - & $98.97 \%$ & $99.02 \%$ \\
\hline Buffer_4 & 133 & 125 & 0 & 8 & $4.05 \%$ & $50.96 \%$ & $76.86 \%$ & $76.84 \%$ \\
\hline Control_diameter & 125 & 124 & 0 & 1 & $3.13 \%$ & - & $96.87 \%$ & $96.53 \%$ \\
\hline Cabling_1 & 33 & 32 & 0 & 1 & $56.65 \%$ & - & $43.35 \%$ & $43.97 \%$ \\
\hline Splicing_1 & 25 & 25 & 0 & 1 & $76.09 \%$ & - & $23.91 \%$ & $24.22 \%$ \\
\hline Control_cord_1 & 2 & 2 & 0 & 1 & $99.85 \%$ & - & $0.15 \%$ & $0.31 \%$ \\
\hline Packing_spool_1 & 3 & 2 & 0 & 1 & $0.00 \%$ & - & $100.00 \%$ & $100.00 \%$ \\
\hline Input_box & 7 & 6 & 0 & 1 & $0.00 \%$ & - & $100.00 \%$ & $100.00 \%$ \\
\hline Packing_pallet_1 & 1 & 0 & 0 & 1 & $0.00 \%$ & - & $100.00 \%$ & $100.00 \%$ \\
\hline Input_pallet & 3 & 2 & 0 & 1 & $0.00 \%$ & - & $100.00 \%$ & $100.00 \%$ \\
\hline Expedition & 0 & 0 & 0 & 0 & $100.00 \%$ & - & $0.00 \%$ & $0.00 \%$ \\
\hline Extending_3 & 33 & 32 & 0 & 1 & $0.42 \%$ & - & $99.58 \%$ & $99.51 \%$ \\
\hline Cabling_2 & 30 & 30 & 0 & 1 & $57.94 \%$ & - & $42.06 \%$ & $42.17 \%$ \\
\hline Splicing_2 & 29 & 29 & 0 & 1 & $74.48 \%$ & - & $25.52 \%$ & $25.04 \%$ \\
\hline Packing_spool_2 & 3 & 2 & 0 & 1 & $0.00 \%$ & - & $100.00 \%$ & $100.00 \%$ \\
\hline Control_cord_2 & 2 & 2 & 0 & 1 & $99.85 \%$ & - & $0.15 \%$ & $0.14 \%$ \\
\hline Packing_pallet_2 & 1 & 0 & 0 & 1 & $0.00 \%$ & - & $100.00 \%$ & $100.00 \%$ \\
\hline Drumming & $\mathbf{3 6}$ & $\mathbf{1 4 3}$ & 0 & 4 & $0.00 \%$ & - & $100.00 \%$ & $100.00 \%$ \\
\hline Extending_2 & 35 & 34 & 0 & 1 & $0.56 \%$ & - & $99.44 \%$ & $99.51 \%$ \\
\hline Extending_4 & 33 & 32 & 0 & 1 & $0.56 \%$ & - & $99.44 \%$ & $99.51 \%$ \\
\hline
\end{tabular}

Table III: Material flow properties after e-Kanban simulation.

\begin{tabular}{|l|c|c|c|c|c|c|c|}
\hline \multicolumn{1}{|c|}{ Object } & $\begin{array}{c}\text { Number } \\
\text { of entries }\end{array}$ & $\begin{array}{c}\text { Number } \\
\text { of exits }\end{array}$ & $\begin{array}{c}\text { Minimum } \\
\text { contents }\end{array}$ & $\begin{array}{c}\text { Maximum } \\
\text { contents }\end{array}$ & $\begin{array}{c}\text { Relative } \\
\text { empty }\end{array}$ & $\begin{array}{c}\text { Relative } \\
\text { occupation } \\
\text { without } \\
\text { interruptions }\end{array}$ & $\begin{array}{c}\text { Relative } \\
\text { occupation } \\
\text { with } \\
\text { interruptions }\end{array}$ \\
\hline Drumming & $\mathbf{1 4}$ & $\mathbf{5 7 2}$ & 0 & 41 & $0.01 \%$ & $99.99 \%$ & $99.99 \%$ \\
\hline Control_diameter & 64 & 64 & 0 & 1 & $99.95 \%$ & $0.05 \%$ & $0.05 \%$ \\
\hline Conveyor & 21 & 14 & 0 & 7 & $6.45 \%$ & $92.33 \%$ & $92.33 \%$ \\
\hline Conveyor1 & 43 & 43 & 0 & 1 & $99.99 \%$ & $0.00 \%$ & $0.00 \%$ \\
\hline Store & 43 & 0 & 0 & 43 & $1.62 \%$ & $0.40 \%$ & $0.40 \%$ \\
\hline Packing_palett_1 & 1 & 0 & 0 & 1 & $0.00 \%$ & $100.00 \%$ & $100.00 \%$ \\
\hline Packing_palett_2 & 3 & 2 & 0 & 1 & $0.00 \%$ & $100.00 \%$ & $100.00 \%$ \\
\hline Input_palett & 5 & 4 & 0 & 1 & $0.00 \%$ & $100.00 \%$ & $100.00 \%$ \\
\hline Buffer & 2 & 2 & 0 & 1 & $100.00 \%$ & $0.00 \%$ & $0.00 \%$ \\
\hline
\end{tabular}




\section{CONCLUSION AND OUTLOOK}

Lean means at first understanding who the customer is and what does he want. In the process of securing customers' requirements is in lean language the eliminating waste wherever is possible, expanding capacity by shortening cycle time and reducing costs. With the introduction of e-Kanban into the management of logistics flows in the researched company, regulated consumption was introduced between interconnected self-regulatory loops in a given production system. For the researched company, it is possible to state a great benefit in terms of visualization of work, which is carried out in a follow-up time frame at the production plant. It is also important in terms of increasing the productivity of the whole system, reducing the level of work in progress, and increasing flexibility. By creating a simulation model, to the researched company was given the opportunity to move further in the digitization process. The potential can be shared in the introduction of real-time monitoring of individual elements via the RTLS network. This implementation would be another step towards the creation of a digital twin of the surveyed company. Managers see the strong effects of digitizing the supply chain by source $[17,18]$, especially in the areas of inventory management, reducing delivery times and the flexibility of the supply chain. In general, there is more transparency, which means more options that can be explored in the decision-making process, leading to better decisions in the supply chain. Approx. $40 \%$ of companies expect that digitization will lead to higher procurement volumes through JIT / JIS, Kanban and lower in-house inventories.

\section{ACKNOWLEDGEMENT}

This article was created by the implementation of the grant project APVV-17-0258 "Digital engineering elements application in innovation and optimization of production flows", APVV-19-0418 "Intelligent solutions to enhance business innovation capability in the process of transforming them into smart businesses", VEGA 1/0438/20 "Interaction of digital technologies to support software and hardware communication of the advanced production system platform", KEGA 001TUKE-4/2020 "Modernizing Industrial Engineering education to Develop Existing Training Program Skills in a Specialized Laboratory" and project ITMS: 26220220182.

\section{REFERENCES}

[1] Bousonville, T. (2017). Logistik 4.0: Die digitale Transformation der Wertschöpfungskette, Springer Gabler, Wiesbaden

[2] Fedorko, G.; Vasil, M.; Bartosova, M. (2019). Use of simulation model for measurement of MilkRun system performance, Open Engineering, Vol. 9, No. 1, 600-605, doi:10.1515/eng-2019$\underline{0067}$

[3] Straka, M.; Khouri, S.; Besta, P.; Drevko, S. (2017). Development of computer simulation and its use for the needs of logistics, Carpathian Logistics Congress (CLC 2017), 86-92

[4] Chovancova, J.; Rovnak, M.; Bogl'arsky, J.; Bogl'arska, L. (2015). Implementation of standardized management systems with focus on their integration, Proceedings of the International Conference on Engineering Science and Production Management (ESPM), 247-252

[5] Rehar, T.; Ogrizek, B.; Leber, M.; Pisnik, A.; Buchmeister, B. (2017). Product lifecycle forecasting using system's indicators, International Journal of Simulation Modelling, Vol. 16, No. 1, 45-57, doi:10.2507/IJSIMM16(1)4.366

[6] Trebuna, P.; Pekarcikova, M.; Edl, M. (2019). Digital value stream mapping using the Tecnomatix Plant Simulation software, International Journal of Simulation Modelling, Vol. 18, No. 1, 19-32, doi:10.2507/IJSIMM18(1)455

[7] Kresak, J.; Caganova, D.; Bindzar, P.; Pajtinkova Bartakova, G. (2018). Use of mining Freight Cableway in urban mobility as a part of an integrated transport system, Acta Montanistica Slovaca, Vol. 23, No. 2, 194-205 
[8] Ojstersek, R.; Acko, B.; Buchmeister, B. (2020). Simulation study of a flexible manufacturing system regarding sustainability, International Journal of Simulation Modelling, Vol. 19, No. 1, 6576, doi:10.2507/IJSIMM19-1-502

[9] Gombar, M.; Kmec, J.; Badida, M.; Sobotova, L.; Vagaska, A.; Michal, P. (2014). The simulation of the temperature effects on the microhardness of anodic alumina oxide layers, Metalurgija Metallurgy, Vol. 53, No. 1, 59-62

[10] Laubertova, M.; Malindzakova, M.; Rosova, A.; Trpcevska, J. (2016). Material flow model of electronic waste sampling and assaying, Przemysl Chemiczny, Vol. 95, No. 7, 1390-1394, doi:10.15199/62.2016.7.23

[11] Plinta, D.; Grznar, P. (2019). Optimisation of production processes with the use of the modelling and simulation method, $14^{\text {th }}$ International Conference on Modern Technologies in Manufacturing (MTeM 2019), Vol. 299, Paper 03007, 6 pages, doi:10.1051/matecconf/201929903007

[12] Fusko, M.; Bučková, M.; Gašo, M.; Krajčovič, M.; Dulina, L.; Skokan, R. (2019). Concept of longterm sustainable intralogistics in plastic recycling factory, Sustainability, Vol. 11, No. 23, Paper 6750, 27 pages, doi:

[13] Grznar, P.; Gregor, M.; Krajcovic, M.; Mozol, S.; Schickerle, M.; Vavrik, V.; Durica, L.; Marschall, M.; Bielik, T. (2020). Modeling and simulation of processes in a factory of the future, Applied Sciences, Vol. 10, No. 13, Paper 4503, 24 pages, doi:10.3390/app10134503

[14] Kudrna, J.; Miller, A.; Edl, M. (2011). Methods of industrial engineering used in network organizations, $17^{\text {th }}$ IBIMA Conference on Creating Global Competitive Economies: A 360-degree Approach, 2037-2042

[15] Straka, M.; Rosova, A.; Lenort, R.; Besta, P.; Saderova, J. (2018). Principles of computer simulation design for the needs of improvement of the raw materials combined transport system, Acta Montanistica Slovaca, Vol. 23, No. 2, 163-174

[16] Bangsow, S. (2015). Tecnomatix Plant Simulation: Modeling and Programming by Means of Examples, Springer, Cham

[17] Wicher, P.; Staš, D.; Karkula, M.; Lenort, R.; Besta, P. (2015), A computer simulation-based analysis of supply chains resilience in industrial environment, Metalurgija-Metallurgy, Vol. 54, No. 4, 703-706

[18] Klos, S.; Patalas-Maliszewska, J. (2014). Badania kluczowych problemów w zarządzaniu utrzymaniem ruchu, Knosala, R. (Ed.), Innowacje w Zarzadzaniu i Inżynierii Produkcji, Polskiego Towarzystwa Zarządzania Produkcją, Opole, 678-687 (in Polish) 